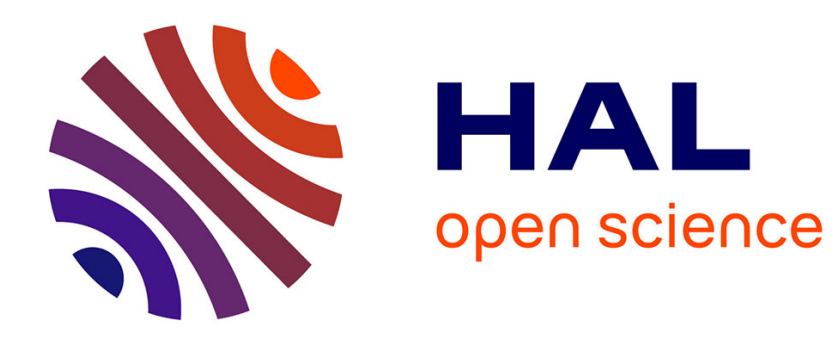

\title{
Statins for heart failure: still caught in no man's land? \\ Stephan von Haehling
}

\section{To cite this version:}

Stephan von Haehling. Statins for heart failure: still caught in no man's land?. Clinical Science, 2008, 116 (1), pp.37-39. 10.1042/CS20080530 . hal-00479451

\section{HAL Id: hal-00479451 https://hal.science/hal-00479451}

Submitted on 30 Apr 2010

HAL is a multi-disciplinary open access archive for the deposit and dissemination of scientific research documents, whether they are published or not. The documents may come from teaching and research institutions in France or abroad, or from public or private research centers.
L'archive ouverte pluridisciplinaire HAL, est destinée au dépôt et à la diffusion de documents scientifiques de niveau recherche, publiés ou non, émanant des établissements d'enseignement et de recherche français ou étrangers, des laboratoires publics ou privés. 


\section{STATINS FOR HEART FAILURE: STILL CAUGHT IN NO MAN'S LAND?}

Stephan von Haehling MD [1]

Institutions:

[1] Applied Cachexia Research, Department of Cardiology, Charité Medical School, Campus Virchow-Klinikum, Berlin, Germany

Total Word Count (excluding references): 1014

Total Word Count (including references): 1947

Number of Figures: 0

Number of Tables: 0

Number of References: 30

Address for correspondence:

Dr Stephan von Haehling, MD

Applied Cachexia Research

Department of Cardiology

Charité Medical School

Campus Virchow-Klinikum

Augustenburger Platz 1

D - 13353 Berlin

Tel.: $\quad+4930450553506$

Fax: +4930450553951

E-Mail: stephan.von.haehling@web.de

\section{ABSTRACT}

Statins are well-known for their ability to lower serum cholesterol levels, but have properties beyond mere cholesterol reduction. These pleiotropic effects include an improvement in endothelial dysfunction, release of endothelial progenitor cells, anti-inflammatory properties, and a number of antitumour activities. In the present issue of Clinical Science, Stunpf et al. show that a 4-week treatmentcourse with the lipophilic atorvastatin ameliorates left ventricular remodelling and function, reduces serum levels of TNFa, IL-6, and monocyte chemoattractant protein-1, and increases both serum and myocardial levels of IL-10. The authors hypothesize that this shift from a pro- to an anti-inflammatory response might be beneficial in the clinical setting, because patients with low levels of IL-10 may fare worse than those with higher levels. This notion requires further investigation, but highlights the need to identify those patients who are likely to benefit from statin therapy.

Statins can lower serum cholesterol levels. That fact is beyond doubt. Patients with or at high risk of atherosclerosis benefit from statin treatment: another fact 
that is well buttressed by a large number of studies in both primary and secondary prevention. However, whether or not cholesterol reduction with statins is an aim worth pursuing in certain chronic conditions is an entirely different matter, and particularly the concept of cholesterol reduction in patients with heart failure (HF) has recently been called into question [1].

The good news about statins is that they possess properties beyond mere cholesterol reduction. These pleiotropic effects include an improvement in endothelial dysfunction [2], release of endothelial progenitor cells, antiinflammatory properties, and a number of anti-tumour activities [3,4]. The improvement in endothelial function mediated by atorvastatin, for example, which has been demonstrated in an elegant animal model of $\mathrm{HF}$ post myocardial infarction, is probably due to an increase in nitric oxide production and a reduction in its inactivation [5]. Atrovastatin at a dose of $10 \mathrm{mg}$ once daily for 4 weeks also achieved an improvement in forearm vasodilatory response to reactive hyperaemia in HF patients [6].

A large number of studies have shown statins' beneficial effects with regards to markers of inflammation including C-reactive protein, tumour necrosis factor- $\alpha$ (TNF $\alpha$ ), and interleukin (IL) 1 and 6 [7--10]. Overactivity of the immune system has been a matter of ongoing concern in HF patients for almost two decades now [11], and especially TNF $\alpha$ and its soluble receptors have been demonstrated to be markers of an adverse prognosis in patients with this disease [12,13]. However, large-scale studies to directly antagonize this cytokine with specific antibodies involving more than 2000 patients ended in disappointment [14,15]. It therefore appears the right time to choose novel weapons in the battle against $\mathrm{HF}$, and the overactivity of the immune system is still an interesting target [16].

As statins possess anti-inflammatory properties, the publication of prospective large-scale studies of these drugs in patients with HF were eagerly awaited. The CORONA (Controlled Rosuvastatin Multinational Trial in Heart Failure) study was a double-blind study that enrolled 5,011 patients with ischaemic disease and an impaired left ventricular ejection fraction who were randomized to placebo or rosuvastatin at a dose of $10 \mathrm{mg}$ once daily [17]. Patients were treated for a median follow-up of 32.8 months. Unfortunately, no significant difference in the primary end-point, a composite of death from cardiovascular causes, non-fatal myocardial infarction, or non-fatal stroke, was noted between the rosuvastatin and the placebo group (hazard ratio [HR] 0.92, 95\% confidence interval [Cl] 0.831.02, $p=0.12$ ). The prospective, multicenter, randomized, double-blind GISSI-HF trial (Gruppo Italiano per lo Studio della Sopravvivenza nell'Insufficienza Cardiaca) was published in late August 2008 [18]. For this study, 4,574 patients were randomized to the same regimen with rosuvastatin $10 \mathrm{mg}$ once daily or placebo. Like with CORONA, there was no difference in the primary endpoints of time to death $(\mathrm{HR} 1.00,95 \% \mathrm{Cl} 0.90-1.12, \mathrm{p}=0.94)$ and time to death or hospitalization for cardiovascular reasons (HR 1.01, 95\% Cl 0.91-1.11, $\mathrm{p}=0.90$ ) between the two study arms. 
The publication of these two studies was a serious blow to the "statins-in-heartfailure" story. An earlier, yet less heeded setback were the results of a prospective study that was initially named the UNIVERSE (Rosuvastatin Impact on Ventricular Remodeling, Cytokines and Neurohormones) trial, in which 86 patients were randomized to placebo or rosuvastatin at an increasing dose (target: $40 \mathrm{mg}$ once daily) in a double-blind fashion [19]. Six months of treatment did not yield any improvement in the plasma levels of C-reactive protein, TNF $\alpha$, IL-6, or B-type natriuretic peptide. Additionally, there was no significant improvement in left ventricular ejection fraction.

One may wonder if these studies should set an end to studying statins in HF. However, as Sir Arthur Conan Doyle pointed out, "it is a capital mistake to theorize before you have all the evidence. It biases the judgement [20]." Thus, one may alternatively wonder if rosuvastatin was simply the wrong statin. Or used at a wrong dose. Indeed, rosuvastatin is one of the very few hydrophilic statins [21], and it has been suggested that lipophilic statins might be able to enter biological membranes more easily which yields more pleiotropic effects [22]. On the other hand, it is intriguing to note that higher cholesterol levels are associated with better (not worse) survival in patients with HF in several retrospective analyses [23,24]. A potential explanation is that cholesterolcontaining lipoproteins can detoxify the bacterial cell-wall component endotoxin $[25,26]$, which appears to play a significant role in patients with HF during oedematous decompensation [27], but it may also be responsible for immune activation in these patients under stable conditions [xi]. The available data should therefore set the stage to undertake studies in HF that fulfill two criteria: (i) to investigate statins at doses that DO NOT lower cholesterol values (but confer pleiotropic effects) and (ii) to use statins other than rosuvastatin and potentially pravastatin, the other hydrophilic substance.

The study by Stumpf et al. in this issue of the Journal comes therefore at the right time [28]. Although the authors do not provide data on cholesterol, they show that a 4-week treatment-course with the lipophilic atorvastatin ameliorates left ventricular remodelling and function, reduces serum levels of TNF $\alpha$, IL-6, and monocyte chemoattractant protein-1, and increases both serum and myocardial levels of IL-10. The authors hypothesize that this shift from a pro- to an antiinflammatory response might be beneficial in the clinical setting, because patients with low levels of IL-10 may fare worse than those with higher levels, as suggested by several studies [29]. This notion highlights another important fact: We need to identify those patients who are likely to benefit from statin therapy. This was not even an inclusion criterion for the studies of antibody therapy against TNF $\alpha$ [30]. It could well be that the levels of pro- or anti-inflammatory markers could help in that sense.

\section{REFERENCES}


[1] von Haehling S, Anker SD. Statins for heart failure: at the crossroads between cholesterol reduction and pleiotropism? Heart 2005;91:1-2.

[2] von Haehling S, Anker SD, Bassenge E. Statins and the role of nitric oxide in chronic heart failure. Heart Fail Rev 2003;8:99-106.

[3] Wong WW, Tan MM, Xia Z, Dimitroulakos J, Minden MD, Penn LZ. Cerivastatin triggers tumor-specific apoptosis with higher efficacy than lovastatin. Clin Cancer Res 2001;7:2067-2075.

[4] Jakobisiak M, Bruno S, Skierski JS, Darzynkiewicz Z. Cell cycle-specific effects of lovastatin. Proc Natl Acad Sci USA 1991;88:3628-3632.

[5] Landmesser $U$, Engberding $\mathrm{N}$, Bahlmann $\mathrm{FH}$, Schaefer A, Wiencke A, Heineke A, Spiekermann S, Hilfiker-Kleiner D, Templin C, Kotlarz D, Mueller M, Fuchs M, Hornig B, Haller $H$, Drexler $H$. Statin-induced improvement of endothelial progenitor cell mobilization, myocardial neovascularization, left ventricular function, and survival after experimental myocardial infarction requires endothelial nitric oxide synthase. Circulation 2004;110:1933-1939.

[6] Tousoulis D, Antoniades C, Bosinakou E, Kotsopoulou M, Pitsavos C, Vlachopoulos C, Panagiotakos D, Stefanadis C. Effects of atorvastatin on reactive hyperemia and inflammatory process in patients with congestive heart failure. Atherosclerosis 2005;178:359-363.

[7] Pahan K, Sheikh FG, Namboodiri AM, Singh I. Lovastatin and phenyl-acetate inhibit the induction of nitric oxide synthase and cytokines in rat primary astrocytes, microglia, and macrophages. J Clin Invest 1997;100:2671-2679. [8] Solheim S, Seljeflot I, Arnesen H, Eritsland J, Eikvar L. Reduced levels of TNF alpha in hypercholesterolemic individuals after treatment with pravastatin for 8 weeks. Atherosclerosis 2001;157:411-415.

[9] Pasceri V, Chang JS, Willerson JT, et al. Modulation of C-reactive proteinmediated monocyte chemoattractant protein-1 induction in human endothelial cells by anti-atherosclerosis drugs. Circulation. 2001; 103: 2531-2534.

[10] Albert MA, Danielson E, Rifai N, Ridker PM; PRINCE Investigators. Effect of statin therapy on C-reactive protein levels: the pravastatin inflammation/CRP evaluation (PRINCE): a randomized trial and cohort study. JAMA 2001;286:64-

70.

[11] Anker SD, von Haehling S. Inflammatory mediators in chronic heart failure: an overview. Heart 2004;90:464-470.

[12] Rauchhaus M, Doehner W, Francis DP, Davos C, Kemp M, Liebenthal C et al. Plasma cytokine parameters and mortality in patients with chronic heart failure. Circulation 2000;102:3060-7.

[13] Ferrari R, Bachetti T, Confortini R, Opasich C, Febo O, Corti A, Cassani G, Visioli O. Tumor necrosis factor soluble receptors in patients with various degrees of congestive heart failure. Circulation 1995;92:1479-86.

[14] Mann DL, McMurray JJ, Packer M, Swedberg K, Borer JS, Colucci WS et al. Targeted anticytokine therapy in patients with chronic heart failure: results of the Randomized Etanercept Worldwide Evaluation (RENEWAL). Circulation 2004;109:1594-602.

[15] Chung ES, Packer M, Lo KH, Fasanmade AA, Willerson JT; Anti-TNF Therapy Against Congestive Heart Failure Investigators. Randomized, double- 
blind, placebo-controlled, pilot trial of infliximab, a chimeric monoclonal antibody to tumor necrosis factor-alpha, in patients with moderate-to-severe heart failure: results of the anti-TNF Therapy Against Congestive Heart Failure (ATTACH) trial. Circulation 2003;107:3133-3140.

[16] von Haehling S, Anker SD. Future prospects of anticytokine therapy in chronic heart failure. Expert Opin Investig Drugs 2005;14:163-176.

[17] Kjekshus J, Apetrei E, Barrios V, Böhm M, Cleland JG, Cornel JH, Dunselman P, Fonseca C, Goudev A, Grande P, Gullestad L, Hjalmarson A, Hradec J, Jánosi A, Kamensky G, Komajda M, Korewicki J, Kuusi T, Mach F, Mareev V, McMurray JJ, Ranjith N, Schaufelberger M, Vanhaecke J, van Veldhuisen DJ, Waagstein F, Wedel H, Wikstrand J; the CORONA Group. Rosuvastatin in Older Patients with Systolic Heart Failure. N Engl J Med 2007;357:2248-2261.

[18] GISSI-HF Investigators. Effect of rosuvastatin in patients with chronic heart failure (the GISSI-HF trial): a randomised, double-blind, placebo-controlled trial. Lancet 2008 Aug 29. [Epub ahead of print]

[19] Krum H, Ashton E, Reid C, Kalff V, Rogers J, Amarena J, Singh B, Tonkin A. Double-blind, randomized, placebo-controlled study of high-dose HMG CoA reductase inhibitor therapy on ventricular remodeling, pro-inflammatory cytokines and neurohormonal parameters in patients with chronic systolic heart failure. J Card Fail 2007;13:1-7.

[20] Ratcliffe S. The Oxford dictionary of quotations by subject. Oxford University Press, New York 2003.

[21] von Haehling S, Anker SD. Statins. In: Hofbauer KG, Anker SD, Inui A, Nicholson JR. Pharmacotherapy of cachexia. Taylor \& Francis, Boca Raton London New York 2006:425-450.

[22] Liao JK, Laufs U. Pleiotropic effects of statins. Annu Rev Pharmacol Toxicol. 2005;45:89-118.

[23] Horwich TB, Hamilton MA, Maclellan WR, Fonarow GC. Low serum total cholesterol is associated with marked increase in mortality in advanced heart failure. J Card Fail 2002;8:216-224.

[24] Rauchhaus M, Clark AL, Doehner W, Davos C, Bolger A, Sharma R Coats AJ, Anker SD. The relationship between cholesterol and survival in patients with chronic heart failure. J Am Coll Cardiol 2003;42:1933-1940.

[25] Rauchhaus M, Coats AJ, Anker SD. The endotoxin-lipoprotein hypothesis. Lancet 2000;356:930-933.

[26] von Haehling S, Schefold JC, Springer J, Anker SD. The cholesterol paradox revisited: heart failure, systemic inflammation, and beyond. Heart Fail Clin 2008;4:141-151.

[27] Anker SD, Egerer KR, Volk HD, Kox WJ, Poole-Wilson PA, Coats AJ. Elevated soluble CD14 receptors and altered cytokines in chronic heart failure. Am J Cardiol 1997;79:1426-1430.

[28] Stumpf C, Petzi S, Seybold K, Wasmeier G, Arnold M, Raaz D, Yilmaz A, Daniel WG, Garlichs CD. Atorvastatin enhances interleukin-10 levels and improves cardiac function in rats after acute myocardial infarction. Clin Sci 2008.

[29] Girndt M, Kohler H. Interleukin-10 (IL-10): an update on its relevance for 
cardiovascular risk. Nephrol Dial Transplant 2003;18:1976-1979. [30] Anker SD, Coats AJ. How to RECOVER from RENAISSANCE? The significance of the results of RECOVER, RENAISSANCE, RENEWAL and ATTACH. Int J Cardiol. 2002;86:123-130. 